\title{
A Comparative Study of Two Different Doses of Hyperbaric 0.5\% Bupivacaine on Saddle Anaesthesia for Perianal Surgeries - A Prospective Study
}

\author{
Dr. Vinayak Gour ${ }^{1}$, Dr Darshana Verma ${ }^{2}$
}

\begin{abstract}
This study was designed in a prospective manner to compare for effects of low dose4.5mg of bupivacaine over high dose $5.5 \mathrm{mg}$ used along with $30 \mathrm{mcg}$ buprenorphine for intra and post-operative analgesia in saddle block for perianal surgeries in patients admitted in shriaurobindo institute of medical sciences indore. Attempts have been made to tailor spinal anaesthesia dose for specific surgical procedures. Several studies targeting local anaesthetic at specific nerve roots supplying the surgical field have demonstrated successful results. 2, 3 However, little research has been published concerning spinal saddle block. This study was designed to examine the efficacy of low dose $4.5 \mathrm{mg}$ bupivacaine for blockade of the nerve supply of the surgical field in perianal procedures compared with the dose $5.5 \mathrm{mg}$ use for saddle anaesthesia, both with $30 \mathrm{ug}$ buprenorphine in addition for post operative analgesia.4, 5 After overnight fasting, blood samples was drawn for complete hemogram, blood urea, serum creatinine, lipid profile. Descriptive and inferential statistical analyses were performed using SPSS version 20.0.
\end{abstract}

Keywords: bupivacaine perineal surgeries

\section{Introduction}

An increasing number of day-case surgeries requires rapid recovery of anaesthetic effects. Surgical anaesthesia should be fast, reliable with rapid recovery and minimal side effects. To compete with modern ambulatory general anaesthesia.

- 'Walk-in, walk-out' spinals with an extremely low dose of bupivacaine and opioids for perianal surgeries created the concept of selective spinal anaesthesiaThe aim of this study is to compare two different doses of (5.5mg and $4.5 \mathrm{mg}$ ) hyperbaric $0.5 \%$ bupivacaine with $30 \mu$ buprenorphine for intra and post operative analgesia in elective perianal surgeries.

Objectives were mainly focused to compare in both groups for:

- The onset time of sensory and motor block at S1 TO S5 level.

- The total number of segments blocked

- The total duration of sensory and motor block

- The requirement of next analgesic dose.

- To evaluate for any adverse events during surgery and first post-operative day.

\section{Materials and Methods}

A total of 80 adult patients of ASA grade I and II scheduled for perianal surgeries were enrolled in this study after getting ethical committee clearance. Patients were randomized either group A or group B drug for saddle block in elective perianal surgeries. Thorough preanaesthetic checkup done. The patients undergone routine preoperative investigative workup done. Received Tab. Alprazolam $0.5 \mathrm{mg}$ at bedtime. NPO for six hours. A written and informed consent was obtained. All preoperative preparation done. A saddleanaesthesia was performed in the sitting position using a $25 \mathrm{G}$ quincke spinal needle. Study drug injected after free flow of CSF. Patients were maintained in sitting position for 7 mins then placed in lithotomy position. In both groups, sensation was tested with toothless clamp gently applied radially, to assess height of sensory block. Onset time for S1-S5 sensory block, motor block and side effects were noted.

\section{Assessment Tools}

- Modified Bromage Scale Bromage 0; patient is able to move the hip, knee and ankle and is able to lift his leg ankle against gravity

BROMAGE 1; patient is unable to lift his leg against gravity but is able to flex his knee and ankle.

BROMAGE 2; patient is unable to flex his hip and knee, but is able to flex his ankle.

BROMAGE 3; patient is unable to flex his hip, knee and ankle, but is able to move his toes

BROMAGE 4; Complete parlay

- Nausea/Vomiting Scale1 no nausea or vomiting2 nausea but no vomiting; no treatment requested3 nausea but no vomiting; treatment requested4 vomiting5 vomiting which persists after treatment

- Pruritis Scale1 None2mild; present but not distressing3 moderately distressing, but treatment not required4severe; treatment requested

All patients remained in the sitting position for $7 \mathrm{~min}$ immediately before and after surgery sensory and motor block were assets. Prospective randomized study, Subjects were randomized by computer random number generator to either group Group 1 - 5.5mg Bupivacaine + $30 \mu$ Buprenorphine Group 2 - 4.5mg Bupivacaine $+30 \mu$ Buprenorphine 


\section{International Journal of Science and Research (IJSR) \\ ISSN (Online): 2319-7064 \\ Index Copernicus Value (2013): 6.14 | Impact Factor (2014): 5.611}

An informed written consent taken from all the patients after the approval of institutional ethical committee.80 patients of ASA I and ASA II, between 18-55 years, undergoing elective perianal surgeries.

\section{Inclusion Criteria}

1) ASA I and ASA II

2) AGE 18-55years

3) Of both sex undergoing elective perianal surgeries

\section{Exclusion Criteria}

1) Patient not fulfilling inclusion criteria

2) Patient refusal

3) Infection at the site of injection

4) Coagulopathy/bleeding disorder

5) Severe hypovolemia

6) Raised ICP

7) Severe valvular heart disease

\section{Results}

The both of drug groups of hyperbaric bupivacaine were successful in saddle block. There is zero motor blockade, no difference in total time of sensory block and number of segments blocked, first and second rescue analgesia given were also insignificant. There is urinary retention in group $\mathrm{B}(\mathrm{p}=0.005)$ The patients were randomly divided into two groups of 40 each and received either of the following drugs intrathecally:

Group 1: hyperbaric 0.5\% 5.5mg bupivacaine plus 30mcg buprenorphine

Group 2: hyperbaric $0.5 \% 4.5 \mathrm{mg}$ bupivacaine plus 30 mcg buprenorphine. In our study groups all the patients were comparable with respect to age, height, weight, sex as well as diagnosis, type of

\section{Observations}

\section{Conclusion}

This block is reliable and excellent patient and surgeon satisfaction. We can conclude that there is lesser urinary retention with group B than group A.

\begin{tabular}{|c|c|c|c|c|c|}
\hline Time & \multicolumn{2}{|c|}{ Group 1 } & \multicolumn{2}{c|}{ Group 2 } & \multirow{2}{*}{ P-Value } \\
\hline $\begin{array}{c}\text { Time to Achieve S1 } \\
\text { Level of Sensory } \\
\text { Block (mins) }\end{array}$ & 6.45 & 1.13 & 6.87 & 0.75 & 0.052 \\
\hline
\end{tabular}

\begin{tabular}{|c|c|c|c|c|c|}
\hline Parameters & \multicolumn{2}{|c|}{ Group 1 } & \multicolumn{2}{c|}{ Group 2 } & \multirow{2}{*}{ P-Value } \\
\hline Total Segments & MEAN & \pm SD & MEAN & \pm SD & \\
\cline { 2 - 5 } Block Above S5 & 5.42 & 0.55 & 5.3 & 0.46 & 0.27 \\
\hline
\end{tabular}

\begin{tabular}{|c|c|c|c|}
\hline Parameters & No & Yes & \multirow{2}{*}{ P-Value } \\
\hline GROUP 1 & 40 & 0 & \\
\hline GROUP 2 & 40 & 0 & 1 \\
\hline
\end{tabular}

\begin{tabular}{|c|c|c|c|c|c|}
\hline \multirow{2}{*}{ Parameter } & \multicolumn{2}{|c|}{ Group 1 } & \multicolumn{2}{c|}{ Group 2 } & \multirow{2}{*}{ P Value } \\
\cline { 2 - 5 } & MEAN & $\pm S D$ & MEAN & $\pm S D$ & \\
\hline Age(Years) & 41.15 & 9.11 & 38.22 & 10.1 & 0.18 \\
\hline Height (Cms) & 159.5 & 7.23 & 161.5 & 7.09 & 0.22 \\
\hline Weight (Kgs) & 61.7 & 11.24 & 61.8 & 7.52 & 0.95 \\
\hline
\end{tabular}

\begin{tabular}{|c|c|c|r|}
\hline Parameters & Male & Female & P-Value \\
\hline Group 1 & 27 & 13 & \\
\hline Group 2 & 26 & 14 & 0.81 \\
\hline
\end{tabular}

\begin{tabular}{|c|c|c|c|c|c|c|}
\hline Diagnosis & $\begin{array}{c}\text { Fissure } \\
\text { in ANO }\end{array}$ & Haemorriods & $\begin{array}{c}\text { Anal } \\
\text { Stenosis }\end{array}$ & $\begin{array}{c}\text { Perianal } \\
\text { Abcess }\end{array}$ & $\begin{array}{c}\text { Anal } \\
\text { Mass }\end{array}$ & $\begin{array}{c}P- \\
\text { Value }\end{array}$ \\
\hline GROUP 1 & 18 & 17 & 1 & 3 & 1 & \\
\hline GROUP 2 & 21 & 18 & 0 & 0 & 1 & 0.37 \\
\hline
\end{tabular}

\begin{tabular}{|c|c|c|c|}
\hline Parameters & ASA 1 & ASA 2 & P-Value \\
\hline GROUP 1 & 33 & 7 & 0.5 \\
\hline GROUP 2 & 34 & 6 & 0.76 \\
\hline
\end{tabular}

\begin{tabular}{|c|c|c|c|c|c|}
\hline $\begin{array}{c}\text { Any Systemic } \\
\text { Abnormality }\end{array}$ & $\mathrm{NO}(1)$ & $\mathrm{HTN}(2)$ & $\mathrm{DM}(3)$ & ASTHMA(4) & \multirow{2}{*}{ P-Value } \\
\cline { 1 - 5 } GROUP 1 & 33 & 4 & 1 & 2 & \\
\hline GROUP 2 & 35 & 5 & 0 & 0 & 0.36 \\
\hline
\end{tabular}

P VALUE $>0.05$ time to Achieve S1 Level of Sensory Block (mins)

\begin{tabular}{|c|c|c|c|c|c|}
\hline \multirow{3}{*}{\begin{tabular}{|c|} 
Time \\
Time to Achieve S1 \\
Level of Sensory \\
B
\end{tabular}} & \multicolumn{2}{|c|}{ Group 1} & \multicolumn{2}{|c|}{ Group 2} & \multirow[b]{2}{*}{ P-Value } \\
\hline & MEAN & $\pm \mathrm{SD}$ & MEAN & $\pm \mathrm{SD}$ & \\
\hline & 6.45 & 1. & 6.8 & 0. & 0.052 \\
\hline
\end{tabular}

Table 11: Time of achievement of S1 level sensory block

The mean time to attain S1 sensory level were shorter in group 1 as compare to group 2 but were statistically insignificant ( $\mathrm{p}>0.05)$.

Total Segments Blocked above S5

\begin{tabular}{|c|c|c|c|c|c|}
\hline Parameters & \multicolumn{2}{|c|}{ Group 1 } & \multicolumn{2}{|c|}{ Group 2 } & \\
\hline Total Segments & MEAN & \pm SD & MEAN & \pm SD & P-Value \\
\cline { 2 - 5 } Blocked Above S5 & 5.42 & 0.55 & 5.3 & 0.46 & 0.27 \\
\hline
\end{tabular}

Table 12: Total segments blocked above S5

Total segment blocked above S5 in both the groups were almost similar and data also statistically insignificant ( $>0.05)$.

\section{Motor Block}

\begin{tabular}{|c|c|c|c|}
\hline Parameters & No & Yes & $\begin{array}{c}\text { P- } \\
\text { Value }\end{array}$ \\
\hline Group 1 & 40 & 0 & 1 \\
\hline Group 2 & 40 & 0 & 1 \\
\hline
\end{tabular}

Table 13: Motor block in patients

There were no motor block seen in both the study group patients and statistically insignificant $\mathrm{p}=1(\mathrm{p}>0.05)$. 
International Journal of Science and Research (IJSR)

ISSN (Online): 2319-7064

Index Copernicus Value (2013): 6.14 | Impact Factor (2014): 5.611

Any Complication during Surgery

\begin{tabular}{|c|c|c|c|}
\hline Parameters & No & Yes & P-Value \\
\hline Group 1 & 40 & 0 & \\
\hline Group 2 & 40 & 0 & 1 \\
\hline
\end{tabular}

Table 14: Any complication during surgery

No complication was seen in both the groups during surgery .No rescue analgesia was required in intraoperative period in both of our study groups $(\mathrm{p}>0.05)$.

\section{Total Duration of Surgery (MINS)}

\begin{tabular}{|c|c|c|c|c|c|}
\hline Parameters & \multicolumn{2}{|c|}{ Group 1} & \multicolumn{2}{|c|}{ Group 2} & \multirow{2}{*}{$\begin{array}{c}\text { P- } \\
\text { Value }\end{array}$} \\
\hline Total I & MEAN & $\pm \mathrm{SD}$ & MEAN & $\pm \mathrm{SD}$ & \\
\hline Surgery (MINS) & 48.5 & 26.07 & 44.25 & 21.35 & 0.427 \\
\hline
\end{tabular}

Table 15: Total duration of surgery

All the patients in our study groups were comparable with respect to mean duration of surgery $(\mathrm{p}>0.05)$.

\begin{tabular}{|c|c|c|c|c|c|}
\hline Parameters & \multicolumn{2}{|c|}{ Group 1 } & \multicolumn{2}{c|}{ Group 2 } & \\
\hline $\begin{array}{c}\text { Total Duration of Post } \\
\text { Operative Analgesia } \\
\text { (MINS) }\end{array}$ & MEAN & \pm SD & MEAN & \pm SD & P-Value \\
\cline { 2 - 5 } & 273.87 & 32.74 & 275.25 & 22.41 & 0.827 \\
\hline
\end{tabular}

Total Duration of Post Operative Analgesia (MINS)

\begin{tabular}{|c|c|c|c|c|c|}
\hline Parameters & \multicolumn{2}{|c|}{ Group 1 } & \multicolumn{2}{c|}{ Group 2 } & P- \\
\hline $\begin{array}{c}\text { Second Analgesic } \\
\text { Dose Given After 1st } \\
\text { Analgesia (MINS) }\end{array}$ & MEAN & \pm SD & MEAN & \pm SD & Value \\
\cline { 2 - 5 } & 360 & 0 & 358 & 6.32 & 0.988 \\
\hline
\end{tabular}

Table 16: Total duration of post-operative analgesia

The mean duration of post-operative analgesia in both the groups were statistically insignificant $\mathrm{p}>0.05$

\section{Second Analgesic Dose Given After 1st Analgesia (MINS)}

Table 18: $2^{\text {nd }}$ analgesic dose given after $1^{\text {st }}$ analgesic dose

\section{Discussion}

\begin{tabular}{|c|c|c|c|c|}
\hline Parameters & Group 1 & Group 2 & P-Value & Remarks \\
\hline Mean time to attain S1 sensory level & $6.45 \pm 1.13$ minutes & $6.87 \pm 0.75$ minutes & 0.052 & statistically insignificant \\
\hline Total segment blocked above S5 & $5.42 \pm 0.55$ segments & $5.3 \pm 0.46$ segments & 0.27 & statistically insignificant \\
\hline Motor block & 0 & 0 & 1 & statistically insignificant \\
\hline Mean duration of post-operative analgesia & $273.87 \pm 32.74$ minute & $275.25 \pm 22.41$ minutes & 0.827 & statistically insignificant \\
\hline First rescue analgesia after saddle block & $279.87 \pm 35.35$ minutes & $288.09 \pm 23.37$ minutes & 0.569 & statistically insignificant \\
\hline Second rescue analgesia after $1^{\text {st }}$ rescue analgesia & $360 \pm 00$ minutes & $358 \pm 6.32$ minutes & 0.988 & statistically insignificant \\
\hline
\end{tabular}

The mean time to supplement of second rescue analgesia since giving first rescue analgesia were statistically insignificant $(\mathrm{p}>0.05)$.

- The baseline mean blood pressure is comparable in both the groups. A little fall in mean blood pressure is observe in both groups after giving saddle block which was found to be statistically insignificant $(p>0.05)$ at different time intervals.

- The difference in mean pulse rate was not statistically significant at any time intervals between the groups $(p>0.05)$ throughout the surgery.

R0SHIDE ET AL6,7,8 used lower doses of hyperbaric bupivacaine and concluded that patients had successful block with zero motor blockade, with early ambulation (96.82 $\pm 15.07 \mathrm{~min})$, no complication, and early home discharge (108.27 $\pm 19.22 \mathrm{~min})$.

The ED50 of hyperbaric bupivacaine for successful saddle block for perianal surgeries was $1.9 \mathrm{mg}$ (95\% confidence interval $=1.7-2.1 \mathrm{mg})$.

\begin{tabular}{|c|c|c|c|c|}
\hline Side Effects & $\begin{array}{c}\text { YES } \\
(n=40)\end{array}$ & $\begin{array}{c}\text { YES } \\
(n=40)\end{array}$ & Percentage & P-Value \\
\hline Respiratory Depression & 0 & 0 & $0 \%$ & 1 \\
\hline Sedation & 0 & 0 & $0 \%$ & 1 \\
\hline Nausea/Vomiting & 0 & 0 & $0 \%$ & 1 \\
\hline Pruritis & 0 & 0 & $0 \%$ & 1 \\
\hline Urinary Retention & 10 & 0 & $25 \%$ & 0.0005 \\
\hline
\end{tabular}

There were no complications and excellent patient and surgeon satisfaction.

We observed patients for side effects and found no respiratory depression, sedation, nausea/vomiting and pruritis intraoperatively and postoperatively in both of our study groups. There is highly significant urinary retention in group 1 as compare to group 2. Group 1 data shows 25 $\%$ have urinary retention where as in group 2 it is nil.

- Prasad ML, et al (1978) ${ }^{9}$ found that acute urinary retention is a common complication following anorectal surgery with a reported incidence of up to $52 \%$, independent of the type of anaesthesia. Tarkkila P1, et al $(1997)^{10} 54$ patients were studied prospectively to evaluate home-readiness after a small dose (1 or $2 \mathrm{ml}$ ) of subarachnoid hyperbaric $0.5 \%$ bupivacaine. Although the sensory and motor block after 1 or $2 \mathrm{ml}$ hyperbaricbupivacaine recovered within a reasonable time for day-case surgery, in some patients recovery of the ability to void was delayed to an undesirable extent

\section{Conclusion}

- Hyperbaric 0.5\% 5.5mg bupivacaine plus 30 buprenorphine and hyperbaric $0.5 \% 4.5 \mathrm{mg}$ bupivacaine plus $30 \mu$ buprenorphine both provides similar and effective saddle aneasthesia for perianal surgery. 


\section{International Journal of Science and Research (IJSR) \\ ISSN (Online): 2319-7064}

Index Copernicus Value (2013): 6.14 | Impact Factor (2014): 5.611

- Both the groups were comparable in all parameters except there is significant urinary retention in group 1 (25\%) as compared to group 2.

- We would recommend low dose of bupivacaine $0.5 \%$ less than $4.5 \mathrm{mg}$ for perianal surgeries to avoid any complication and early recovery.

- Planning for optimizing saddle block with still a lower dose of Bupivacaine. (ongoing project)

\section{References}

[1] Huffnagle SL, Norris MC, Huffnagle HJ, Leighton BL, Arkoosh VA. Intrathecal hyperbaric bupivacaine dose response in postpartum tubal ligation patients. Reg Anaesth Pain Med 2002; 27: 284-8.

[2] Valanne JV, Korhonen A, Jokela RM, Ravaska P, Korttila KK. Selective spinal anaesthesia: a comparison of hyperbaric bupivacaine $4 \mathrm{mg}$ versus 6 mg for outpatient knee arthroscopy. AnaesthAnalg 2001; 93:1377-9.

[3] Kuusniemi KS, Pihlajamaki KK, Pitkanen MT. A low dose of plain or hyperbaric bupivacaine for unilateral spinal anaesthesia. Reg Anaesth Pain Med 2000; 25:605-10.

[4] Greenwald M, Johanson C, Moody D, et al. Effects of buprenorphine maintenance dose on mu-opioid receptor availability, plasma concentrations, and antagonist blockade in heroin-dependent volunteers. Neuropsychopharmacology 2003; 28(11):2000-9.

[5] Johnson RE, Fudala PJ, Payne R. Buprenorphine: considerations for pain management. J Pain Symptom Manage 2005; 29(3):297-326 